\title{
Anne Eriksen:
}

THE MEDICAL PERIODICALS OF J.C. TODE AND THE IDEA OF PUBLIC HEALTH

About the author:

Professor in Cultural History, University of Oslo

Address: IKOS, P.O. Box 1010 Blindern, N-0315 Oslo

e-mail: anne.eriksen@ikos.uio.no

tel: +4722856989

\section{Bio:}

Anne Eriksen is a professor in cultural history at the University of Oslo. Her fields of research are eighteenth century medical history, eighteenth century antiquarianism, museums, heritage and cultural memory. Her latest book is From Antiquities to Heritage (Berghahn Books 2014). Other major publications are Topografenes verden. Fornminner og fortidsforståelse (Pax forlag 2007) and Museum. En kulturhistorie (Pax forlag 2009).

\section{Abstract:}

In 1770 "Den medicinske Tilskuer" (The Medical Spectator) was published in Copenhagen. The man behind it was the surgeon, physician and poet Johann Clemens Tode. This was the first of all together sixteen journals on health and medicine that Tode was to write, edit and publish until his death in 1806. With his journals, Tode contributed significantly to making health a public issue. This implies conceptualizing health and medicine as reaching beyond the private sphere and individual lives and rather concerning society at large. To understand the late eighteenth century, it is equally important to see that the idea of "public health" also implies the existence of a public sphere. The article argues that Tode's journals contributed to the making of such a public and that he did so by addressing its health. It investigates how the readers and-more generally - the public were staged and produced in Tode's medical periodicals. The object of investigation is not primarily the medical advice given by Tode as much as the way it is given, the figures or personae that it is given to and the public that it helped to create.

Key-words: public health; eighteenth century; periodicals; Johann Clemens Tode. 


\section{THE MEDICAL PERIODICALS OF J.C. TODE AND THE IDEA OF PUBLIC HEALTH}

In 1770, a new journal was published in Copenhagen, the capital of the twin kingdoms of Denmark and Norway. Its title was Den medicinske Tilskuer - The Medical Spectator - and the man behind it was the surgeon, physician and poet Johann Clemens Tode. The Medical Spectator was the first of sixteen medical periodicals that Tode edited and published until his death in 1806. In the same period he also edited several journals of literary criticism and published his own poems and plays, as well as other works on medicine and health. ${ }^{1}$ Tode's activities distinguish him as a person who eagerly explored and exploited the new periodical media and their potential for communication, entertainment, debate and knowledge transmission. Ethnologist and cultural historian Signe Mellemgaard has argued that his medical publications make Tode a good example of the late eighteenth century ambition of "turning health into a discursive object". ${ }^{2}$ This article will build on her assertion and examine how this project of turning health into a discursive object by means of popular periodicals also made it a public issue. As indicated by the modern notion of public health, this implies conceptualizing the field of health and medicine as something that reaches beyond the private sphere and individual lives, and rather concerns society at large. However, to understand the situation in the late eighteenth century, it is equally important that "public health" also implies the existence of a public or a public sphere. The article will argue that Tode's journals contributed to making such a public and that he did so by addressing its health. It will investigate how the readers and - more generally - the public are staged and produced in Tode's medical periodicals. The object of investigation is therefore not so much the medical advice given by Tode as the way it is given and the figures or personae that it is given to: How does Tode address his readers, and how does he make them appear in the periodicals? What roles and what qualifications are they ascribed? These readers may be "real" in the sense that they were individuals who actually read or at least bought the publications, or they may be fictional in the sense that they existed in the texts only. This distinction is not what is most important here. What is going to be investigated is how Tode as an author and a publisher textually presents and converses with a public and how this public is constituted through the discourse on health.

Before commencing on this exploration of his journals, some biographical information is appropriate. Tode was born in Germany in 1736, but made his career in Denmark. His apprenticeship as a surgeon led him to Copenhagen in 1757. Through his teacher, the wellconnected C.F. Wohlert, Tode was introduced at court, and appointed royal surgeon from 
1763. The life at court, with its polite entertainments and cultural possibilities suited the sociable Tode well, and it was only reluctantly - according to his biographer Schmiegelow that he accepted a grant from his patrons who wanted him to go abroad to study medicine. ${ }^{3} \mathrm{He}$ visited Leyden, Edinburgh, London and Paris, and was granted his medical degree when he returned to the University of Copenhagen in 1769 . Tode continued his career as a practising physician, a university professor and finally as head of the university, but most of his time was spent writing and publishing. Of his very large number of works, which also included poetry, only a selection of the publications concerning popular medicine will be considered here.

Judging from his medical publications, Tode's view on medicine was profoundly influenced by his views on dietetic and hygienic medicine. One of the main tasks of the physician - or the medical advisor - was to help people preserve their health and prevent illness or ill health. For this reason, Tode pays much attention to food, drink, air and climate, rest and exercise in his writings. In short, he appears as the typical neo-Hippocratic vitalist, ascribing great significance to the influence of the non-naturals and the individual constitution. Mellemgaard points out that nearly all his publications on health and medicine were directed at educated and well-to-do readers. They were supposed to know foreign languages, and their health was conditioned by a quite affluent lifestyle. ${ }^{4}$ The journals abound with quotations in English, Italian, French and Latin, as well as German. The latter was Tode's mother tongue, and one of the major languages in Denmark-Norway. Italian and French were the fashionable languages, while the Latin of the learned world and the English of the mercantile probably had fewer readers. Tode's focus on luxury goods, rich food and digestion problems further underscores the social profile described by Mellemgaard. In a certain sense, Tode may thus be considered a doctor of the traditional kind, offering his services to wealthy patrons and combining his medical work with cultural and social pastimes. ${ }^{5}$ On the other hand, he also worked at the public hospital and the orphanage in Copenhagen, both of which were poor relief institutions. His work in popular medicine can be said to combine these two aspects. They made medical knowledge less exclusive and more generally accessible, even if it was not intended to reach all parts of society.

\section{Periodicals in the Enlightenment}

Periodical publications were an important feature of Enlightenment culture. Even if not a totally new medium, journals and newspapers abounded in the period from the late seventeenth century onward. Journals from the period span from scientific publications like 
the Philosophical Transactions of the Royal Society in London (from 1662) to those presenting new books and shorter reports from the world of learning, and further to the moral and entertaining weeklies like the Spectator (from 1711) or the Mercure Galant (from 1678). Some were short-lived initiatives, others had a longer lifetime. Taken as a whole, this wide range of periodical publications represents a remarkable manifestation of intellectual and cultural energy, as well as of new kinds of entrepreneurship. Nonetheless, what has made the periodicals so important in later scholarship is not their abundance alone, but the role ascribed them by Jürgen Habermas and other theoreticians of the public sphere. The periodicals have appeared as the enlightened media par excellence, representing and illustrating the main features of the new public sphere. They have been held to literally embody the "reason which through public use of the rational faculty was to be realized in the rational communication of a public consisting of cultivated human beings", ${ }^{6}$ and to represent a direct continuation as well as a materialization of the public discussions in the coffee-houses. In the critical debate over the habermasian model, on the other hand, literary scholar Neil Saccamano has pointed out that Habermas has overlooked the profound differences between conversation and print culture. The juxtaposition of the two forms of communication made by Habermas ignores the important performative aspect of the journal, Saccamano argues: the possibility the writers' had to stage themselves as new personae. ${ }^{7}$ It has also been pointed out that the habermasian model presents a far too smooth and unilinear development, putting too much emphasis on rational debate and argument and on a shared understanding of the common good. When investigated in their motley plurality, eighteenth century periodicals do not present an image of a "public consisting of cultivated human beings" or a sphere of "private persons coming together as a public", but appear rather as a multivocal chaos of ideas and projects, quarrels and invectives, criticism and entertainments, banal frivolities, as well as political and commercial interests. ${ }^{8}$

Tode's multitude of periodical publications shares a number of the features that generally are held to be distinctive of Enlightenment periodicals. With their expressed aim of making the public healthy, the journals demonstrate how periodicals contributed to making health public by introducing medical issues into the field of general discourse. As this article will seek to demonstrate, the journals also stage a reading public and a public sphere, even if they may not really have created it. Moreover, despite their various names, Tode himself considered his long row of different periodicals on health issues as parts of the same project. ${ }^{9}$ The diversity resided above all in the titles, while the journals themselves followed much the same pattern. Seen as a whole, the titles appear as the result of a continuous effort to frame or 
encircle a specific field of knowledge, as well as a way of communicating it. Even this was typical of eighteenth century periodicals, according to literary scholar Aina Nøding, who argues that the absence of a fixed terminology was representative of the flexibility and creativity of the new media. ${ }^{10}$ Tode himself pointed out that his often short-lived journals succeeded one another not so much because of failure with their public as for a wish for novelty. He argued that he kept changing the names with the aim of obtaining new subscribers because people always want to have their journals "from the start". ${ }^{11}$ This craving for novelty - whether it came from the public or from the editor himself - is yet another distinctive feature of the periodicals, enhancing their status as a new type of media, and addressing enlightened persons of flexible and impatient minds.

\section{The Medical Spectator and subsequent journals}

By the end of 1787 Tode congratulated himself for having published his journal for nine consecutive years - changing titles notwithstanding. This means that he himself dates the beginning of the project to 1778, when he launched his Sundhedstidende (The Health Gazette). His very first medical periodical was nonetheless the Den medicinske Tilskuer (The Medical Spectator), appearing as early as 1770-1771. This journal represents Tode's initial efforts to carve out ways of talking about issues of health and medicine with a general public, and does as such merit some attention. The journal's title relates directly to Steele and Addison's Spectator, which first appeared in London 1711. It set an international standard for the moral weeklies as a genre, and also lent its name to several of them. Several journals with this type of name had already been published in Copenhagen. Der Nordische Aufseher was issued from 1758 to 1761 and was followed by Den Patriotiske Tilskuer (The Patriotic Spectator) from 1761 to 1763 . Before that, la Spectatrice Danoise had appeared from 1748 to 1750.

Distinctive features of the spectator journals were the fictive editor who presented him- or herself as a real but enigmatic figure, and texts that discussed current issues of taste, morals and elegant behaviour, frequently in some kind of dialogue with their readers. In this, we may already recognize the theatrical or performative aspect of the journals, as pointed out by Saccamano: while the editor or editorial group, on the one hand, present themselves as specific characters, they obviously also are staged figures playing their roles. ${ }^{12}$ With their addresses to their readers, in the form of issues to be discussed or questions to be answered, there lies a corresponding invitation to the readers to enter into the play as well. ${ }^{13}$ At the same time, this form opens rich possibilities for fictive readers to be staged in the pages. 
In the first issue of his Medical Spectator, Tode very emphatically places the physician in the role of spectator. In the great tragicomedy of human life, he writes, an infinity of spectators exists. Nonetheless, nobody, however learned or clever he is, has more or better opportunities to make observations than the physician. ${ }^{14}$ What kind of observations does this privileged position make possible? According to Tode, the physician is distinguished by his access to that unique source of knowledge and truth that is experience. Furthermore, he can always consult the inimitable book made by God himself - nature. And, finally, he is in the position to follow members of the human race in their deepest despair as well as greatest happiness. The physician thus appears as the ideal spectator of the theatre of human life, as this figure paradigmatically presents himself. Nonetheless, more specialized perspectives soon emerge, and the spectator is transformed into a person more particularly knowledgeable in health and medicine. It seems that Tode finds the detached position and general wisdom of the spectator persona insufficient to convey his message. An important element in this is his insistence that the authority of the physicians ought to be better recognized in society, and should agree more with the public utility of their competence and services. This is acknowledged "elsewhere", but not yet in Copenhagen, he writes. For this reason the "medical spectator" has to content himself with communicating his observations in the periodical, but the situation is not ideal.

Presenting the physician as spectator, then, does not merely mean to adapt a wellestablished figure of the periodical world to his own interests. It is also linked with an argument about the public position of physicians and the public use of medical knowledge. When Tode strives to make medicine a public issue by means of his journal, it is as a critical response to the physicians' lack of more real and effective influence in society. On the one hand, this stand can be seen as an argument that an increasing medicalization of society was on its way. On the other hand, it can also be taken to support historian of medicine Roy Porter's argument that early modern medical popularization rather was an expression of the opposite. It took place - as Tode says - exactly because no public health institutions or programs existed. $^{15}$

Tode soon dropped the idea of staging himself as a spectator, and the majority of his subsequent periodicals on health and medicine were named gazettes, journals and weeklies (Tidende, Blad, Journal, Uge-Blad). These terms all refer to the periodical nature of the publications, and convey the impression that this was the most distinctive feature of the project. They mark an emphasis on the ephemeral, changing, diverse and composite character of the periodical publications and the performances that they made possible. Moreover, the 
names all represent ways of organizing and presenting knowledge to a general audience that refer to already established forms, genres and institutions. As such, the names and concept used can be seen as representing "stages" that enable different types of activity or performance. What they also do is apply these forms and set the stage for the specific field of health and medicine.

Tode chose titles like Sundhed og Underholdning (Health and Entertainment, 1787); Hygcea og Muserne (Hygæa and the Muses, 1788) and Museum for Sundheds- og Kundskabselskere (Museum for the lovers of Health and Knowledge, 1789). The first, Health and Entertainment, can be seen as an echo of the typical eighteenth century idea of uniting utility and pleasure, combining useful instruction with light amusement. The combination of Hygæa, the classical goddess of health, with the muses partly expresses the same ideal. Tode does not only seek to make medical information entertaining in itself, he also refers more directly to art and literature, which was his own other field of activity. The Museum finally represents the collection, available to the curious seeker of knowledge. While museums today mainly are public places for exhibitions and displays, early modern museums worked more as places for research and as nodes in networks of learning. For this reason, the term museum did not only mean collections of material objects, but might also refer to libraries or to other sites for study, collections and knowledge production. ${ }^{16}$ During the eighteenth century the term was commonly used for journals that presented rather loosely collected and preferably entertaining material on a certain field or directed toward a specific group, be it children, ladies or poets.

Tode's Sundhedstidende appeared from 1778 to 1781 and became the reference point for his subsequent publications, most directly reflected in titles like Nye Sundhedstidende (the New Health Gazette) and Nyeste Sundhedstidende (the Newest Health Gazette). It is also this journal that marks the start of what Tode himself (above) regarded as a nine-year period of continuous publication. The following exploration will make Sundhedstidende its case, and investigate how Tode strove to create and stage a public on the pages of his journal.

\section{Enter centre stage: the public}

When it first appeared in 1778, Sundhedstidende was equipped with a preface that sought to present the idea of the journal. Further argument was given in an article published over the first two issues. This is where Tode spells out his ideas about why and how health information should be presented to the general public, as well as what he expects from this public. In the earliest address to his readers Tode's description of his venture is elaborate and cautious. He 
seeks to explain what a health gazette is, and what its readers could expect. His explicit models are the Gazette Salutaire, published from 1761 in Bouillon (today's Belgium) and the French Gazette de Santé (from 1773). Tode also refers to an older Parisian Gazette de Santé from the middle of the century, and to the Gazette d'Epidaure which no longer appear. The existence of four different periodicals allows Tode to consider them as a group or genre, and to explain to his readers what kind of information such journals normally would contain. It is obvious that even if Tode is starting a new journal of a new kind, it is not the novelty as such that is his main argument. His point is rather that he is the one to introduce this kind of periodical in the local context of Copenhagen and the kingdom of Denmark-Norway. "Elsewhere" - as Tode often writes when he refers to other European countries - the health gazette has already been established. His argument implies that the new journal will bring his subscribers on a par with the fashion of other countries. He also makes it clear that his new journal is no mere idiosyncrasy, but that he is following a European lead.

In addition to borrowing the name, Tode models the contents of his journal(s) very explicitly on these established publications. A medical gazette, he explains, will usually publish "short dissertations, or excerpts from dissertations concerning the natural economy of the human body: the dangers that always threaten life and health, the help and salvation which nature and art may offer against them; the errors of the body and the way to correct them, and the type of occurrence where the legally trained person may profit from the enlightenment of a physician". ${ }^{17}$ He goes on to point out that by this means, the public will be able to read about illnesses caused by the seasons, the weather, their way of life, their amusements, the fashions, the occupations, as well as about epidemics and contagions. Moreover, the journal will inform its readers about everything that is being done by the authorities, the estates and the learned societies to the benefit and health of the human race: Discoveries, experiences, investigations and improvements concerning dietetics and the medical art. And what will above all distinguish the presentations of such issues is "the constant variability, the entertaining presentation and the many amusing anecdotes with which the journal is interspersed". ${ }^{18}$

Tode frequently uses the term "the public" (Publicum). It seems to designate both his actual audience and a more unspecified group. In this last meaning, the term can be said to refer to a public sphere, consisting of private persons who are interested in sharing information, opinion and argument. Adopting an interest in measures taken by the authorities, and in discoveries made by learned societies relating to the welfare of "the human race", is also typical of this public. Its members will be diverted by the constant novelty of the journal, 
Tode claims. Nonetheless, the continuous changes also demand their full attention. Indirectly then, a person subscribing to the journal and taking part in this public sphere is portrayed as intellectually and mentally agile, amused rather than stressed by novelties and variation, open to new knowledge and insights and having interests that reach beyond his own position and immediate needs. ${ }^{19}$

Who are these persons? Tode divides them into three groups. The first are those whose busy lives do not give them time to read all new books, disputations, programs, memoirs, magazines, libraries, journals and newspapers where this kind of information usually is presented. A weekly of merely four pages will give them all the information they need in a condensed form. The second group comprises those who live a distance from the capital and outside the literary circuit. The journal will keep them up-to-date with what is going on in the world of medicine. Finally, the third group comprises people who do not have access to medical knowledge due to the "barbaric technical language" normally used by physicians. In the journal they will find easily intelligible information. In this way, Tode presents his journal as a medium for popularization and general dissemination of medical knowledge, but the aim is obviously not to reach the lower social groups. All three reader-groups appear to consist of well-informed persons who, due to other responsibilities in life (and the defects of medical literature), need condensed and accessible information about important matters. The description also shows Tode's awareness of rival information sources and media, and presents the world of his fashionable readers as one of information overload and a swirling flow of competing novelties.

In the next issue, Tode elaborates on the argument by addressing his readers even more directly. He expects something from them and requests all his "gentlemen colleagues" physicians and surgeons, as well as vicars and other provincial people with some knowledge of medicine, to send him relevant material. He also encourages his subscribers more in general to contribute: If anybody has a question fit for the journal, Tode will print the letter as well as his own response. The precondition is that "such letters are received without expense, that the inquirer gives his proper name, and that the question is of interest to the public and worthy of an answer". ${ }^{20}$ With these requests, Tode is quite explicitly staging a public of active readers and defining their performances. Rules are established for the performance.

Anonymity is not allowed, and the queries that are posed shall not merely interest the enquirer himself, but be relevant as a contribution to a public sphere of informed readers and writers. Tode demands a specific kind of competence from all his readers. The professional knowledge of the physicians is one element in this, but equally important is the common will 
to share and discourse upon matters that are of general interest. What Tode requests from his readers is the competence to perform in a public sphere.

The role of health and medicine in creating this sphere becomes obvious when Tode refers to the medical news that he is planning to present to his readers as beneficial to "the human race", rather than as services for privileged individuals. The invitation to take part in a public discourse on such issues situates the readers in a network where their willingness to share (professional) information and to pose questions that do not (only) concern themselves and their own health, is exactly what makes them participants in a public sphere.

\section{Dialogue and discourse}

Despite Tode's pressing invitation for readers to contribute with their knowledge and/or queries, he often has to admit that in actual fact the journal has been produced by him alone. The readers do not respond as requested. Apart from a very small number of letters from fellow physicians, the texts have been written by Tode himself. However, this does not make the gazette appear monologic. Tode employed a number of strategies to give the journal a conversational form and to create the image of a continuous dialogue between the editor and his public.

The very first letter received by Tode was printed a few weeks after the journal had been launched and answered by him in the subsequent issue. It is announced as "by Mr. N", and acknowledged by Tode in his answer as written by a highly respected colleague. The letter concerns "cold treatment" for smallpox. ${ }^{21}$ The writer argues that the radical novelty of cold treatment is without equal in contemporary medicine, but asks if it may not cause harm: During smallpox, the body seeks to rid itself of the poisonous matter. As cold treatment gives the patient fewer pustules, is there not a risk that some matter will remain in the body, or cause harm by seeking other ways out? The letter is quite long, and its writer appears well informed about medical theory. Tode's answer is even longer, and fills half the next issue. He presents a list of twenty-four arguments as to why cold treatment is not harmful, making use of the occasion to present a thorough, medical discussion of smallpox theory. ${ }^{22}$ The immediate context of both question and answer was a smallpox epidemic that was raging in Copenhagen, giving the issue far more than theoretical interest. Tode had commenced his comments on the epidemic a couple of weeks earlier, at the end of July. His advice and discussion about the best precautions and treatments continued well into October. During this period, he also received one more question from the same person, this time concerning inoculation. Is it not so that a certain disposition is required in the individual for smallpox to 
break out? And will those who lack this disposition really benefit from inoculation? ${ }^{23}$ Again, this letter supplies Tode with the possibility of rehearsing some staple arguments in favour of inoculation. ${ }^{24}$ Even if the letters actually were written by one of Tode's colleagues, they may well have been composed at the instigation of Tode himself.

Subsequent letters to the editor that are published by Tode are different, and easily recognized as fictive. The first of these also concerns inoculation. The letter, signed by "Miss O.P.Q", who confesses to being seventeen years old, brims over with misspellings and poor grammar. The young Miss is worried that "inokilation" will rob her of her "complession", as a certain person of her acquaintance says it will. Or is this other person just jealous, and wants her "reavench" because the writer is the better looking of the two? In this case, Tode's answer is short and reassuring. There is no need for anxiety. ${ }^{25}$ Even if the issue of inoculations causing people to look pale figured among the common anti-inoculation arguments, Tode presents the theme in a jocular way through the letter from a rather silly girl. A similar strategy is employed in other letters. While the epidemic still raged, Tode "received" another letter, signed Peter, asking him to drop the long articles about smallpox in favour of more pressing issues like the dangers of fashion. Tode's earlier promise to treat this subject is what made Peter subscribe to the journal, but so far he - and indeed others with the same interest has been disappointed. To specify the request, Peter exemplifies by referring to the "silken cuirasses" worn by fashionable men, their wigs like brooms and the tassels on their shirts, as well as the enormous shoe buckles. When it comes to female fashion, it is the high heels, the rolls of artificial hair and the long plumes in the hats that particularly worry him. He cites a number of cases to argue that the plumes in particular are dangerous. In the short anecdotes that follow the plumes scare horses and oxen, catch fire and even get stuck to a man passing with a bucket of tar. As the hat follows the plumes and the head follows the hat, this unhappy encounter leads to the woman being dragged along until the fellow has the "presence d'esprit" of letting go of his bucket. ${ }^{26}$ Once again Tode makes his answer short, but enters into the pseudo-serious tone set by the letter. He also defends himself against the accusation of broken promises. The Medical Spectator, Tode writes, discussed issues of women's fashion, only to awake the fury of his female readers. The fair sex did not approve of his writings about their "afternoon caravans" and their coffee drinking habits. He now hopes that he will not reignite rage by "arguing against an adornment that becomes the fair so well, and to change a taste that is too well rooted". 27

Most of the subsequent letters to the editor have this character. They present a question or introduce a subject that Tode wants to write about. The letter writers most often 
present their questions in ignorant, even bluntly stupid ways, far from Tode's own elegant form. The question might be one that Tode knows is relevant to the public, even if it is not a matter for serious medical argument - like that of "complession" and "inokilation". It also enables him to present arguments that may provoke, using another voice than his own, thus he cannot be held fully responsible - as in the case of the hat plumes.

Hypochondriacs are a favourite topic with Tode, and his ridicule of them emerges in different ways and contexts. In December 1779 Tode presents a letter from a man in the provinces. This figure presents a long and detailed description of himself, his constitution and his health problems, which are related to his stomach and digestion. The letter is interspersed with medical terminology and anatomical references all the way through. It mentions the use of numerous medical remedies and cures, all presented in the most technical language. Tode starts his answer by stating that the sufferings of this patient clearly demonstrate the harmful effects of reading medical literature and taking too many different medicines. They are probably the main cause for the man's ill health, which Tode diagnoses to be "colic, hypochondria and hemorrhoids." 28

That these letters were meant to be understood as entertaining fiction is obvious from the names of the pretended authors. Tode presents letters from "Beergard Hopscrubb", "Oyster", "Ailing" and "Mr. Ironhead". ${ }^{29}$ Names that are less obvious constructions, like Mr. Peter and Miss O.P.Q, or the figure of the provincial hypochondriac, also appear to be fictive. They represent other social groups than Tode's actual subscribers, as they are known from the lists, and also differ from the affluent and well educated readers that are implied by Tode's texts in general.

The fictive letters should not be seen as substitutes for a failed dialogue with real readers. Not only are the letters and their writers too obviously fictional, they are also clearly outsiders to the public that Tode generally addresses. This public, as it was conceptualized by eighteenth century intellectuals, was a minority and an elite, a small group of men of letters who took part in philosophical and political debates and circulated their arguments in print. Cultural historian Roger Chartier points out how the "public" and the "popular" were considered to be "an irreconcilable dichotomy" in the period, and how later historians correspondingly have asserted that "the public was not a people" in revolutionary France. ${ }^{30}$ Chartier also underscores that, sociologically, the new public sphere that emerged during the late eighteenth century "was distinct from the court, which belonged within the domain of public power [i.e. the absolute state], and from the people, who had no access to critical debate. This is why this sphere could be qualified as 'bourgeois"'. ${ }^{31}$ For all its liberal 
ambitions and democratic implications, this "tribunal of reason and justice" as it was termed by its theorists, ${ }^{32}$ was not supposed to consist of servant girls worrying about their

"complession" or provincials about their haemorrhoids.

In Tode's journals, the common people are ascribed a rather traditional role as comic figures, distinguished mostly by their ignorance and their simple ways. The letters and figures composed and presented by Tode to amuse his readers indicate that he trusts his competent readers not only to see through the fictional names and figures, but also to recognize and appreciate his jocular use of some main features of periodical literature. One reason for his confidence was that this kind of play with fictional identities and fictive characters in itself was a staple element in the new periodicals. It defined and dominated journals in the spectator genre, but it was also fundamental to the general theatricality and performativity of the periodicals as such.

In actual fact, letters from readers were not Tode's most important means for maintaining the idea of a journal in dialogic conversation with its public. Two other strategies were far more systematic, if less conspicuous: The use of queries and the reference to times, seasons and celebrations, as well as climate and weather conditions. The smallpox epidemic in 1778 has already been mentioned. Presenting advice and reports about what to do to avoid the disease, how to care for the patients and so on was obviously of very direct interest to readers living in the midst of an epidemic. Other references are less dramatic, but no less relevant. In April, Tode presents a "Warning to those, who believe that spring is finally here." ${ }^{33}$ In October and November he writes about the harmful effects of cold air, but also about the risks of eating roast goose, the traditional meal for Martinmas. The reason was not the fat and heavy food in itself (even though it might be harmful to delicate stomachs), but a goose disease in the rural districts around Copenhagen that supplied its markets with meat. ${ }^{34}$ Medically, Tode's preoccupation with season and climate are clearly related to his neoHippocratic ideas and the emphasis on dietetics: Disease was largely due to the influence of the non-naturals. For Tode as an editor, the same topics served another function as well. They lent his articles an air of actuality and created an impression of intimacy with his readers. Even if the public did not discernibly respond to his invitations to engage in a dialogue, Tode's choice of topics and themes can be read as very direct responses to the actual experiences of his readers.

Headlines in the form of questions are also frequently used by Tode. Are beetroots wholesome? Are irregular meals harmful? Can one safely eat puff pastry? Which is the best corn plaster? On which occasions are emetics useful? Are shrimps wholesome? Can one live 
without meat and fish? Tode makes no attempt to present these questions as if they actually had been sent to him by readers. However, the inquiries presented mostly concern foodstuffs and diet, and remedies for common complaints and illnesses. Issues relating to the weather and the seasons are also frequent. Easily related to the everyday life and experiences of the readers, the questions are short and written in a simple language. Consequently, despite being made up by Tode, they resemble what might have been posed by the readers, and concern issues directly relevant to them.

In some cases, Tode's answers are brief. The best remedy for corns is a simple diachylon plaster, left for some days before the corn is peeled away. ${ }^{35}$ Shrimps are not so unwholesome as might be believed. Even if their meat is hard and the taste salty, and they are too small to be chewed well, they give the stomach some resistance and keep digestion active. Hence, they may be a good remedy for "weak and spoilt" stomachs, but should not be taken by persons suffering from rheumatism, rash or scorbut (scurvy). ${ }^{36}$ The short answers of this kind contain hardly any discussion and may well be read as practical advice about what to do and how to proceed in specific everyday cases. Most often, however, the answers are quite elaborate and take the form of small treatises. Concerning emetics, the answer spans over two issues of the gazette, and consists of the enumeration of more than thirty illnesses and complaints that may all be alleviated by this means. They include all kinds of fevers, poisoning, intestinal worms, nose bleeding, smallpox, over-eating, as well as prophylactic use when one has visited somebody stricken by epidemic disease or is just feeling unwell. The reason for this universality is that emetics not only serve to cleanse the stomach, Tode explains. Vomiting also rids the body and lungs of phlegm, it may eliminate cramps, improve exhalations of the skin and lighten headaches. ${ }^{37}$ The article written to argue this is a quite comprehensive exposition of medical principles and theories belonging to humoral pathology and dietetics. The examples to which he refers do not appear as specific cases to learn from or to imitate, but rather as illustrations of these principles. Even if it is easy to imagine the initial question as posed by a random reader of the gazette, the answer can hardly have been illuminating to a non-professional wondering in what cases provoked vomiting would relieve the pains of an ill person.

Discoursing on the subject of whether humans can live without eating meat and fish, Tode strikes yet another note, involving both philosophical issues and anthropological information in an entertaining and diverting essay. His starting point is that the cruelty it causes animals makes tender-hearted persons question the necessity of humans killing to obtain food. Tode also points out that "those who are wise by profession", in particular Jean- 
Jacques Rousseau, have argued against meat. While "the good Jean-Jacques" builds this argument on "so-called humanity", Tode's answer is a reference to the bible and the way God has set humans above all animals and birds, and given us the right to eat them. ${ }^{38}$ His more elaborate argument, however, concerns not God but "nature": Those who argue against meat seem to have forgotten that nature has supplied us with teeth and a stomach well fit to eat and digest meat. They also forget that "nature has given most living creatures instincts and abilities to kill and eat other living creatures". ${ }^{39}$ After this initial argument a number of examples of persons or groups of persons reported to have lived without eating meat follow. Tode presents Canadian Indians, ancient athletes, "certain Brahmins", people in Naples, negroes and wild people, seafarers, Egyptian hermits, Arabs, Christian monks, and, more particularly, Hermann Boerhaave and Isaac Newton. He also refers to what these persons or groups are said to have subsisted on: milk, honey, dates, fruit, cocoa beans and so on. Even if possible, however, it cannot be said to be wholesome for humans to live on such food alone, Tode argues. In particular, it is not recommended for Europe's northern regions, our health cannot bear a diet without meat, it would lead to a lack of appetite, colour and strength, and result in a bad stomach and nerves. Moreover, our northern climate does not produce the abundance of fruits and vegetables that might serve in the place of meat. "Could the Norwegian and the Icelander subsist on the yield of their unrewarding soil and the few berries from trees? No, the good and wise Creator has therefore given them fish and fowl so they can enjoy their satisfaction". ${ }^{40}$ Tode obviously delights in his long row of "fun facts" and curious anecdotes about non-meat eaters. Just as obviously, he expects his readers to be so well versed in the writings and philosophy of "the good Jean-Jacques" that explanations are superfluous. In this way, the answers to seemingly simple questions that might have been asked by actual readers and that take everyday concerns as their starting point, give Tode the occasion to elaborate on medical issues that he finds important, as well as to write texts that clearly are intended to entertain his public.

\section{Assessing the public}

Did Tode succeed? His own evaluations of his work can be found in the annual prefaces intended for the binding of each volume. More indirectly these texts can also be read as assessments of how a public was being created through the discourse on issues concerning its health. By the end of 1778, after his first year of weekly publications, Tode concluded that the gazette had been a success. He presented a list of 442 regular readers, headed by the king, the queen, the crown prince and the heir presumptive, and declared proudly that the most wise 
and good persons in the country were among his readership, as well as those of the highest rank. ${ }^{41}$ Moreover, his most eager readers were to be found among the most enlightened persons, he claims. To judge from the names and titles on the list, this wise and enlightened public consisted mainly of civil servants and men from the mercantile bourgeoisie. Physicians, surgeons and apothecaries also figure on the list, together with a smaller number of nobility. As far as can be judged, the actual subscribers correspond well with what has already been said about the implied readers of the gazette.

The self-congratulatory text that was published in 1787, after nine continuous years of periodic publications (above), also seems to confirm that his ideas had been well received. Not only could Tode at this point flatter himself with a steady number of about 400 faithful subscribers, the lack of a more explicit argument in favour of the journal also indicates that an understanding was well established. Writing in 1787, Tode also makes a point of the fact that for the last few years it has not even been necessary to publish the list of subscribers, which was a common strategy for bolstering the authority of a journal. ${ }^{42}$

Despite the success, the journal also met with criticism. Tode groups the objections that have been raised into five categories, answering them all. Those who feel he should stick with each issue until it has been exhausted, are deemed ignorant of the fact that diversity and novelties are the prime advantages of periodical publications. Those who have been offended by the light and entertaining tone of the gazette, and do not find this fitting for medical information, "are probably still of the old belief that learning ought to be as inseparable from seriousness as thoroughness from dryness. But in our age one has become used to associate the useful with the entertaining: Even the most beneficial and important truth becomes grating when it is presented in the stiff and scholastic way. He who now will enlighten must therefore first learn the art of entertaining". ${ }^{43}$ Even some of those who actually have enjoyed the entertainment have found Tode's satirical tone inappropriate for a physician, but seem to not understand that for a person of high sensibility satire is hard to avoid when commenting on harmful ways of living. Tode's answer to those who want him to write for a lay public is simply a refusal to publish a journal that will invite derision from his colleagues. Finally, he has been criticized for publishing treatments and cures that have not yet been sufficiently tested for their safety, and thus should not be taken into use. However, Tode says in these cases that his presentations have been so brief that only the most experienced physician would understand how to imitate the novelties in his own medical practice.

It is worth noting that the majority of these objections concern the nature of periodical publications, the competence they require from their public and hence the creation of a 
specific kind of public. Tode's answers centre on the contrast between the old and the new, fashionable and enlightened. He is emphatic that to enjoy a periodical the reader must appreciate diversity and swift changes and understand close connections between utility and entertainment. Furthermore, the reader must accept that the editor and writer is a man of high sensibility, and that this fact sets its stamp on the way things are presented. The sensible writer himself, on the other hand, is not only a man of learning and a good physician, he must also know how to give his learning an entertaining form. Once again Tode does not merely present his journal, he also portrays - and instructs - a competent public of enlightened and modern readers.

Tode's initial answers are self-confident, and he presents himself as a man of the future. In later years his tone grew somewhat more acerbic, however, even though the criticism seems largely to have remained the same, showing concern about the satirical form and Tode's way of poking fun at the things he finds harmful to people's health. The need to defend himself leads Tode into an argument over the nature of the public. He flatters himself that his most faithful and understanding readers are "the people" or "the nation", rather than the plebeians and common people. Building on this opposition, Tode argues that the plebs have had the insolence to "usurp the name and rights of the public". As a "false public" (in Tode's own words) these people have judged and criticized the gazette, while the readers who are lovers of truth have defended him against the parrots or "cacadou en colére": "For nothing can more deprive an outspoken writer of his energy and courage, than when he sees that any numbskull, any garbage without impunity may take the liberty to decipher his intentions and judge his heart...". 44

The argument refers to the understanding of the public as "a tribunal of reason and justice", and of public opinion as a hallmark of an enlightened age, as described by Chartier. ${ }^{45}$ At the same time, it demonstrates some of the problems of this idea. Tode conceives of his audience as a "false" public. In his view, plebeians have neither the right nor capability to take on the role of a public and practise critical judgment. Their criticism is nothing but furious prattle. In this way, Tode's discontent can typically be said to reflect the eighteenth century ideas of the popular and the public as an "irreconcilable dichotomy." ${ }^{46}$ But who are these impudent persons? They are not merely ignorant people from the poor suburbs, Tode maintains. They also come from "the best parties" of the city; they are "our small lords and ladies, our dawdlers and fools". This makes the opposition between the public and the population or the "false public" less simple. The unlawful public does not simply comprise the common people or plebeians. It might be people, independent of class, who lack the 
competence to give their criticism the form that is required for a public sphere, who are too rude or too supercilious in their judgment. Or are they simply people Tode does not like much because they have objections to his journal? While the question cannot be answered, the situation elucidates some tensions inherent in the idea of reason produced as "the rational communication of a public consisting of cultivated human beings" and of the public as an ideal critical instance. ${ }^{47}$ What kind of criticism was welcomed, and who were allowed the right to present it? How could unwanted criticism be dismissed by denying its proponents a legitimate place?

With his prefaces, Tode presents his arguments concerning the nature of periodical literature, the competence and rights of the readers as participants in a public sphere and his own role as a writer. His comments can be read as a defence against critics as well as a portrayal of the structure and functions of a (critical) public sphere. He instructs and condemns, directs performances and sets the stage. He also seems more interested in discussing periodical publications and the public than issues of medicine. It also seems that the objections against the journals largely were related to his style of presentation. It is the idea that medicine and health information can be presented to a general audience in a humorous and diverting manner that met with opposition and complaints. Tode was accused of lacking thoroughness, of tomfoolery and silliness, and of treating serious matter too lightly. The complaints represent ideas about how medical information can be made public and generally accessible, and if it should be so at all. They concern Tode as a writer with a distinct - rather light - style, but also relate to the subject matter itself. Does medicine have to be serious? Difficult to understand? Crammed with specialized theory and technical language? Reserved for professionals? What happens when it becomes merry, entertaining and easy to read, presented as poetry and anecdotes or as simple, concrete instructions? And must the professionals accept having their work examined, summarized and even perhaps ridiculed in a weekly that is read by persons who know nothing of medicine and are only out to be amused?

Tode made the health issue public through his journals, where the expressed aim was also to make the public healthy. As the explorations have shown, this also involved the production of a competent public of readers who appreciated both the form of a periodical publication and the idea that medical information could be presented in entertaining and easily accessible ways. However, it should also be clear that Tode's efforts to produce a public and turn health into a public issue differs from a modern notion of "public health" in important ways. Above all, Tode's advice on health and medicine does not concern the population at large, even if it is seen as a public concern. Differing from, for instance, the Swiss physician 
Tissot's hugely successful books providing popular health information, published largely during the same period, Tode's journals did not address a population, neither as readers of his texts nor as the object of the medical advice that was given. In Tode, the common population, the poor and the peasants all remain largely invisible. When they appear, it is as funny figures in rather traditional ways. They are ignorant, stupid and superstitious, but what is more important is that no ideas of change are presented: Being the laughing stock of the educated and elegant is simply the fixed role of the common people. Tode has no aim to educate and enlighten the population, to improve its living conditions or state of health. Arlette Farge has pointed out how even prominent Enlightenment thinkers and social reformers appeared to be blind to the sufferings of the poor, whether the cause was disease or bad living conditions. She ascribes this blindness to a deep understanding of the lower classes as fundamentally different - physiologically as well as emotionally - from the elite. ${ }^{48}$ This pattern seems to be reflected even in the writings of Tode. The public that he works to stage is in no way identical with the population at large.

Tode is innovative and modern, but also profoundly traditional. On the one hand, he presents illness and ill-health as general problems. Anybody may be afflicted by them, as they are conditioned by environmental factors (the non-naturals) and by food, drink, lifestyle and so on, rather than by the unique constitution, temperament or humoral state of each person. Consequently, improvements in health care or medicine may reasonably be presented as beneficial to "the human race" at large, and hence a matter for society as a whole. On the other hand, however, the recipient of the medical advice is always addressed as an individual. Even when a piece of advice is presented as favourable to all, it is not advocated as a general measure to be adopted universally or organized as a program. The idea is not, for instance, that public health in Copenhagen would benefit from the inhabitants not eating goose as long as the stock supplying its meat markets might be infected. It is rather presented as being up to the individual not to take risks with these geese, and to seek their own, safer suppliers for the traditional Martinmas meal. Despite his work to make health public, then, Tode gives no indication that he sees the questions of health as a general issue relevant to the population at large. Rather, his idea of "public health" coincides with his notion of an enlightened, reading public - "the nation" in his own terminology. In this way, Tode for all his self-proclaimed modern projects and innovative strategies remains a rather traditional society physician, reserving his professional aid to the affluent and fashionable. 


\section{Bibliography}

Chartier, Roger. The Cultural Origins of the French Revolution. Duke University Press: Durham and London, 1991.

Chartier, Roger. Forms and Meanings. Texts, Performances, and Audiences from Codex to Computer. Philadelphia: U. of Pennsylvania Press, 1995.

Darnton, Robert. Poetry and the Police. Communication Networks in Eighteenth-Century Paris. Belknap: Harvard, 2010.

Findlen, Paula 1989. The Museum: Its Classical Etymology and Renaissance Genealogy. Journal of the History of Collections, nr. 1, p. 59-78.

Farge, Arlette. La déchirure. Souffrance et déliason sociale au XVIIIe siécle. Montrouge: Bayard, 2013.

French, Roger. Medicine before Science. The Business of Medicine from the Middle Ages to the Enlightenment. Cambridge: Cambridge U.P., 2003.

Habermas, Jürgen. The Structural Transformation of the Public Sphere. Cambridge Mass.: MIT Press, 1991.

Hooper-Greenhill, Eilean. Museums and the Shaping of Knowledge. London: Routledge, 1992.

Krefting, Ellen. "Feminine forkledninger. La Spectatrice Danoise i 1700-tallets tidsskrifthistorie". In Opplysningens tidsskrifter. Norske og danske periodiske publikasjoner på 1700-tallet, edited by Eivind Tjønneland, 37-60. Bergen: Fagbokforlaget, 2008.

Krefting, Ellen, Aina Nøding and Mona Ringvej. En pokkers Skrivesyge...1700-tallets dansk-norske tidsskrifter mellom sensur og ytringsfrihet. Oslo: Scandinavian Academic Press, 2014.

Larsen, Øivind 1991. "Sundhedstidende og Johann Clemens Tode". In Sundhedstidende 1778-1781, edited by Øivind Larsen and Bengt I. Lindskog, 7-16. Oslo: Universitetet i Oslo.

Lindemann, Mary. Medicine and Society in Early Modern Europe. Cambridge: Cambridge University Press, 2010.

Mellemgaard, Signe. Kroppens natur. Sundhedsopplysning og naturidealer i 250 år. København: Museum Tusculanum Press, 1998.

Nøding, Aina. "Hva er et 1700-tallstidsskrift?" In Opplysningens tidsskrifter. Norske og danske periodiske publikasjoner på 1700-tallet, edited by Eivind Tjønneland, 3-14. Bergen: Fagbokforlaget, 2008.

Porter, Dorothy. Health, Civilization and the State. A history of public health from ancient to modern times. London: Routledge, 1999.

Porter, Roy. "Introduction". In The Popularization of Medicine 1650-1850, edited by Roy Porter, 116. London and New York: Routledge, 1992.

Porter, Roy. Bodies Politic. Disease, Death and Doctors in Britain, 1650-1900. Ithaca, New York: Cornell University Press, 2001. 
Saccamano, Neil 1991. "The Consolations of Ambivalence. Habermas and the Public Sphere". Modern Language Notes 106, (1991): 685-698.

Schmiegelow, E. Johan Clemens Tode. En biografisk kulturhistorisk Skitse. København: Nyt Nordisk Forlag, 1941.

Tissot, Samuel Auguste André David. Avis au peuple sur sa santé ou traité des maladies les plus fréquentes. 2nd ed. Paris: F. Didot le Jeune, 1762.

Tjønneland, Eivind. "Innledning". In: Opplysningens tidsskrifter. Norske og danske periodiske publikasjoner på 1700-tallet, edited by EivindTjønneland, i - xvii. Bergen: Fagbokforlaget, 2008.

Tode, Johan Clemens. Den mediciniske Tilskuer, Kiøbenhavn: Peder Horrebow, 1770-1771.

Tode, Johan Clemens. Sundhedstidende. Et medicinskt Ugeskrift af blandet Indhold. Kiøbenhavn: Peder Horrebow, 1778-1781.

Tode, Johan Clemens. Nye Sundheds-tidende for Aaret ... Kiøbenhavn: Peder Horrebow, 1782-1783.

Tode, Johan Clemens. Sundhedsblade. Fra 26. Jul. 1785 til 18. Aug. 1786. Kiøbenhavn: Peder Horrebow, 1785-1786.

Tode, Johan Clemens. Sundhed og Underholdning. Kiøbenhavn: P. Horrebow, 1787.

Tode, Johan Clemens. Hygae og Muserne. En Fortsattelse af Sundhedstidenden,

Sundhedsbladene og Sundhed og Underholdning. Kiøbenhavn: Peder Horrebow, 1788.

Tode, Johan Clemens. Museum for Sundheds-og Kundskabs-elskere. Kiøbenhavn: Peder Horrebow, 1789.

\section{Notes}

${ }^{1}$ Schmiegelow, Johan Clemens Tode; Larsen, Sundhedstidende og Tode, $12 \mathrm{f}$.

2 Mellemgaard, Kroppens natur, 112.

${ }^{3}$ Schmiegelow, Johan Clemens Tode, $15 \mathrm{f}$.

${ }^{4}$ Mellemgaard, Kroppens natur, 112.

${ }^{5}$ See French, Medicine before Science.

${ }^{6}$ Habermas, The Structural Transformations, 35.

7 Saccamano, "The Consolations of Ambivalence"; Tjønneland, "Introduction".

${ }^{8}$ Krefting, Nøding and Ringvej, En pokkers skrivesyge.

${ }^{9}$ Mellemgaard, Kroppens natur, 112.

${ }^{10}$ Nøding, "Hva er", 5.

11 Tode, Sundhed og Underholdning, 373.

12 Saccamano, "The Consolations of Ambivalence".

${ }^{13}$ Krefting, "Feminine forkledninger"; Krefting, Nøding and Ringvej, En pokkers skrivesyge.

14 Tode, Den medicinske Tilskuer, 1.

${ }^{15}$ R. Porter, "Introduction", 3.

${ }^{16}$ Hooper-Greenhill, Museums and the Shaping; Findlen, The Museums.

${ }^{17}$...smaa Afhandlinger, eller Udtog af Afhandlinger om Naturens Huusholdning i Mennekset: om de Farer, som ideligen true Liv og Sundhed: om den Hjelp og Redning, som Natur og 
Konst formaae derimod at anvende: om legemlige Feil og deres Rettelse: og om saadanne Hændelser, hvor den Lovkyndige kan være tient med Lægens oplysning. Tode, Sundhedstidende 1778, 1.

18 "...Den idelige Afvexling, den fortællende Skrivemaade og de indstrøede Anecdoter." Tode, Sundhedstidende 1778, 1.

${ }^{19}$ Tode consequently adresses his reader as male.

20 "... at slige Breve tilsendes mig postfrie; at Den, som spørger, nævner sig med sit rette Navn; og at Spørsmaalet virkeligen er værd at besvares og interessant for Publicum". Tode, Sundhedstidende 1778, 5.

${ }^{21}$ Like other patients with fever, people suffering from smallpox had traditionally been kept very warm to "sweat the fever out". Cold treatment consisted of exposing the patient to fresh air and cold water instead, and was contested by many.

${ }^{22}$ Tode, Sundhedstidende 1778, 28; $30 \mathrm{ff}$.

${ }^{23}$ Tode, Sundhedstidende 1778, 44.

${ }^{24}$ Tode, Sundhedstidende 1778, 48.

${ }^{25}$ Tode, Sundhedstidende 1778, 108.

${ }^{26}$ Tode, Sundhedstidende 1778, 68.

27 ... at ivre imod en Prydelse, som klæder de Skiønne saa vel, og ved at rykke ved en Smag, som har festet alt for dybe Røtter. Tode, Sundhedstidende 1778, 72.

${ }^{28}$ Tode, Sundhedstidende 1779, 108.

${ }^{29}$ Øllegaard Humlekjær, Musling, en Skranting, Hr. Jernhue.

${ }^{30}$ Chartier, The Cultural Origins, 27.

${ }^{31}$ Chartier, The Cultural Origins, 20.

${ }^{32}$ Chartier, Forms and Meanings, $10 \mathrm{ff}$.

${ }^{33}$ Tode, Sundhedstidende 1780, 17.

${ }^{34}$ Tode, Sundhedstidende 1778, 121.

${ }^{35}$ Tode, Sundhedstidende 1779, 98.

${ }^{36}$ Tode, Sundhedstidende 1780, 185.

${ }^{37}$ Tode, Sundhedstidende $1780,161 \mathrm{ff}$.

${ }^{38}$ Tode, Sundhedstidende 1780, $185 \mathrm{f}$.

${ }^{39}$ De glemme, at Naturen har indprentet de fleeste levende Skabninge en Drift og en Ævne til at dræbe og æde andre levende Skabninger. Tode, Sundhedstidende 1780, 186.

${ }^{40}$ Mon Nordmanden og Islændingen kunde behielpe sig med den utaknemmelige jords Grøde og Træernes faa Bær? Nei, den gode og vise Skaber haver derfor given dem Fisk og Fugle, at de skulle mættes med Velbehag. Tode, Sundhedstidende 1780, 188.

${ }^{41}$ For the next two years, annual lists of new subscribers were printed, showing an annual increase of about one hundred subscribers. No information exists, however, about subscriptions that may have been terminated in the same period.

${ }^{42}$ Tode, Sundhed og Underholdning, 373.

${ }^{43}$ De ere uden Tvivl endnu af den gamle Troe, at Lærdom bør være ligesaa uadskillelig fra Alvorlighed, som Grundighed fra Tørhed. Men i vore Tider er man bleven vant til at forbinde det nyttige med det Moersomme: den gavnligste, den mest magtpaaliggende Sandhed bliver skurrende, naar den fremsættes i den stive og kolde skolostiske Tone. Den som nu vil oplyse, maae først lære den konst at underholde. Tode, Sundhedstidende 1778, upag.

${ }^{44}$ For intet kan meere betage en reentalende Skribent Lyst og mod, end naar han maae see, at enhver Dosmer, ethvert Skarn ustraffet tør tage sig den Frihed, at tyde hans Hensigter og at bedømme hans Hjerte. Tode, Sundhedstidende 1779, pag.

${ }^{45}$ Chartier, Forms and Meanings, $10 \mathrm{ff}$.

${ }^{46}$ Chartier, The Cultural Origins, 27. 
${ }^{47}$ Habermas, The Structural Transformations, 35.
${ }^{48}$ Farge, La déchirure, 69ff. 